\title{
Regional Distribution of General Practitioners and Consultants in the National Health Service
}

\author{
J. M. LAST,* M.B., D.P.H.
}

Brit. med. F., 1967, 2, 796-799

This study, one of a series on aspects of medical manpower, deplcyment, and recruitment, was designed to discover the extent to which individual medical schools in Britain supply the administrative regions of England and Wales with doctors. My objective was to test two hypotheses: firstly, that doctors settle near the place where they lived in their youth rather than near the medical school they attended, if home and medical school were in different regions; and secondly, that consultants are less likely than general practitioners to settle in the region where they lived in their youth, opportunity to pursue a specialist career being for them a higher priority than choice of a place to live.

\section{Methods}

I sent a postal questionary (see Appendix) to a $10 \%$ probability sample of general practitioners and consultants in England and Wales (a separate investigation is required in Scotland, where the supply-demand relation is quite different). The universe for the sample consisted of lists of doctors maintained by the Ministry of Health, current at 30 September 1965. The sample was drawn by officers in the Statistical Branch of the Ministry of Health, London, for whose technical assistance I am grateful. Information on the situation of permanent or family home during attendance at medical school, supplied in response to the questionary, was categorized into the Registrar General's standard regions for analysis. These divisions are coarse but suffice to show the principal regional variations in patterns of settlement. When respondents indicated that their permanent home changed from one region to another during their medical education, the region closest to their present address was coded for analysis. Since only $3 \%$ of respondents moved in this way, only a negligible bias was introduced.

After a pilot study in March 1966, questionaries were posted in July 1966, and reminder letters (with a copy of the questionary) in September 1966. Data were coded and punched on 80 -column cards for analysis.

\section{Results}

The initial mailing produced an approximately $80 \%$ response from both general practitioners and consultants. Reminder

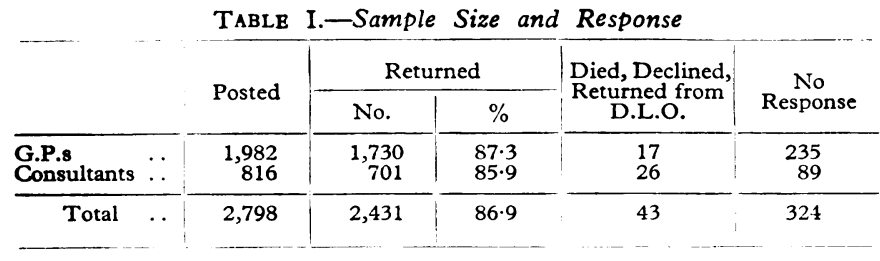

letters raised the response rate to $87 \%$ of general practitioners and $86 \%$ of consultants (Table I). The analyses which follow have been carried out on questionaries returned by 1,730 general practitioners and 701 consultants.

\footnotetext{
- Department of Social Medicine, University of Edinburgh.
}

Like all retrospective studies, this one suffers from bias due to selective factors which had operated previously: by definition, only the doctors remaining in England and Wales could be included. This has to be remembered when the output of medical schools is considered.

\section{Catchment Areas of Medical Schools}

In England and Wales $36 \%$ of general practitioners and $49 \%$ of consultants attended medical schools in London. The greater contribution of London schools to consultant than to general practice manpower is significant at the $1 \%$ level. A further $28 \%$ of general practitioners and $24 \%$ of consultants attended medical schools elsewhere in England. The remainder received their medical training outside England and Wales; $17 \%$ of general practitioners and $16 \%$ of consultants attended Scottish medical schools and $8 \%$ of general practitioners attended medical schools in Ireland (including Queen's University, Belfast). Edinburgh University makes the largest single contribution to the supply of general practitioners in England (7\%) and is also the second largest source of supply of consultants (7\%), exceeded only by St. Bartholomew's Hospital Medical School (9\%). St. Bartholomew's and the London Hospital Medical College share with Edinburgh the distinction of contributing more than $6 \%$ of general practitioners in England and Wales (Table II). The figures in Table II can be multiplied by 12 to produce approximate estimates of the number of general practitioners and consultants supplied by

\begin{tabular}{|c|c|c|c|}
\hline & & General Practitioners & Consultants \\
\hline $\begin{array}{l}\text { Charing Cross } \\
\text { Guy's } \quad \ldots \\
\text { King's } \quad \ldots \\
\text { London } \quad \ldots \\
\text { Middlesex } \quad \ldots \\
\text { Royal Free } \\
\text { St. Bartholomew's } \\
\text { St. George's } \quad . \\
\text { St. Mary's } \\
\text { St. Thomas's } \\
\text { University College } \\
\text { Westminster .. } \\
\end{array}$ & $\begin{array}{ll}\ldots & \ldots \\
\cdots & \cdots \\
\cdots & \cdots \\
\cdots & \cdots \\
\cdots & \cdots \\
\cdots & \cdots \\
\cdots & \cdots \\
\cdots & \cdots \\
. & \cdots\end{array}$ & $\begin{array}{r}17 \\
86 \\
40 \\
104 \\
58 \\
23 \\
102 \\
27 \\
40 \\
54 \\
52 \\
16\end{array}$ & $\begin{array}{r}9 \\
39 \\
27 \\
37 \\
31 \\
16 \\
65 \\
8 \\
29 \\
42 \\
30 \\
11\end{array}$ \\
\hline \multicolumn{2}{|c|}{ Total London } & $619(36 \%)$ & $344(.49 \%)$ \\
\hline $\begin{array}{l}\text { Birmingham } \ldots \\
\text { Bristol } \\
\text { Cardiff, Welsh Natior } \\
\text { Durham, Newcastle } \\
\text { Leeds } \\
\text { Liverpool } \\
\text { Manchester } \\
\text { Sheffield }\end{array}$ & $\begin{array}{l}\cdots \\
\cdots \\
\cdots \\
\cdots \\
\cdots\end{array}$ & $\begin{array}{l}63 \\
31 \\
35 \\
66 \\
87 \\
88 \\
78 \\
43\end{array}$ & $\begin{array}{r}25 \\
9 \\
17 \\
17 \\
28 \\
46 \\
23 \\
5 \\
\end{array}$ \\
\hline \multicolumn{2}{|c|}{ Total " Provincial" } & $491(28 \%)$ & $170(24 \%)$ \\
\hline $\begin{array}{ll}\text { Oxford } & * \\
\text { Cambridge* } & \cdots \\
\end{array}$ & 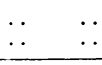 & $\begin{array}{l}23 \\
31 \\
\end{array}$ & $\begin{array}{r}12 \\
2 \\
\end{array}$ \\
\hline $\begin{array}{ll}\text { Aberdeen } & \ldots \\
\text { Edinburgh } & \ldots \\
\text { Glasgow } & \cdots \\
\text { St. Andrews } & \cdots \\
\end{array}$ & $\begin{array}{l}\cdots \\
\cdots \\
\cdots\end{array}$ & $\begin{array}{r}51 \\
122 \\
94 \\
20 \\
\end{array}$ & $\begin{array}{l}16 \\
52 \\
31 \\
11\end{array}$ \\
\hline \multicolumn{2}{|c|}{ Total Scottish } & $287(17 \%)$ & $110(16 \%)$ \\
\hline $\begin{array}{l}\text { Belfast } \\
\text { Eire ... } \quad . \\
\text { Commonwealth } \\
\text { European } \quad . . \\
\text { Other and unstated } \\
\end{array}$ & $\begin{array}{l}\ldots \\
\cdots \\
\cdots\end{array}$ & $\begin{array}{r}53 \\
114 \\
33 \\
38 \\
92\end{array}$ & $\begin{array}{l}10 \\
22 \\
16 \\
12 \\
17\end{array}$ \\
\hline Total & .. & 1,730 & 701 \\
\hline
\end{tabular}

* Oxford and Cambridge graduates have been classified in the clinical school they attended, when this information was given. 
each medical school to England and Wales in 1966. For example, this calculation indicates that about 1,200 general practitioners and a little under 800 consultants in England and Wales attended St. Bartholomew's.

Table III shows the number and percentage of general practitioners supplied by medical schools to each of the standard regions in England and Wales. Here, as in Table V, which shows the regional distribution of consultants, those who attended Oxford and Cambridge are included with graduates

TABLE III.-Number and Percentage of General Practitioners Supplied by Medical Schools to the Standard Regions of England and Wales



of London medical schools and Belfast graduates are included with others from Ireland. London schools make a major contribution to general practice manpower in Southern and SouthEastern England as well as in London, and only in Yorkshire does their contribution fall below $10 \%$ of the total. Scottish medical schools supply more than a fifth of the total in the four northern regions of England and more than $10 \%$ in every region except Wales. The contribution of Irish medical schools is greatest in the North Midlands and North-Western England - the regions closest to Ireland. The provincial medical schools make an important contribution to general practice manpower in their own regions, but graduates of provincial schools are outnumbered by Londoners in regions close to London, and almost outnumbered by Scots in regions on the border. The evidence of Table III suggests that medical schools tend to supply general practitioners to adjacent rather than to remote regions.
However, there is a closer association between present residence of general practitioners and the region in which they resided while attending medical school (Table IV). Thus $51 \%$ of general practitioners who as students were resident in England and Wales have settled in the region of their permanent home at that period. Table IV also shows that those who came from outside England and Wales have settled mainly in the regions most accessible to their homeland: the Scots in the North, the Irish in the West, the Commonwealth and foreign graduates in London and South-East England. There is no evidence of a "drift to the South-East"; if anything, the reverse has occurred. The northward and westward movement into general practice and consultant appointments is, no doubt, a result of the laws of supply and demand, and reflects regional differences in the ratio of applicants to vacancies. When the analysis is repeated on cohorts graduating up to 1939, 1940-9, and since 1950, a secular trend emerges: movement out of the SouthEast was greatest among graduates in the period 1940-9. Movement into England and Wales from Scotland and Ireland has decreased progressively from the earliest to the more recent of these periods.

Tables $\mathrm{V}$ and VI show the corresponding figures for consultants. Table $\mathrm{V}$ gives the proportion of consultants supplied to each standard region of England and Wales by London, Scottish, Provincial, and Irish medical schools, and Table VI shows the relation between region of permanent home during student life and present residence of consultants.

TABLE V.-Number and Percentage of Consultants Supplied by Medical Schools to the Standard Regions of England and Wales

\begin{tabular}{|c|c|c|c|c|c|c|}
\hline \multirow{3}{*}{$\frac{\text { Region }}{\text { N. England }}$} & \multicolumn{5}{|c|}{ Medical Schools Supplying Region } & \multirow[b]{2}{*}{$\begin{array}{l}\text { Total } \\
100 \%\end{array}$} \\
\hline & $\begin{array}{c}\text { London } \\
\text { Schools } \\
(+ \\
\text { Oxbridge) }\end{array}$ & $\begin{array}{l}\text { Scottish } \\
\text { Schools }\end{array}$ & $\begin{array}{c}\text { Irish } \\
\text { Schools } \\
(+ \\
\text { Belfast) }\end{array}$ & \multicolumn{2}{|c|}{$\begin{array}{l}\text { Main Provincial } \\
\text { Schools }\end{array}$} & \\
\hline & 12 & 20 & - & Durham .. & $11(20 \%)$ & 54 \\
\hline E. and W. & $\begin{array}{l}(22 \%) \\
11 \\
(26 \%)\end{array}$ & $\begin{aligned}(37 \%) \\
8\end{aligned}$ & $\begin{array}{c}1 \\
(2 \%)\end{array}$ & Leeds .. & $9(21 \%)$ & 42 \\
\hline $\begin{array}{l}\text { N.W. } \\
\text { England } \\
\text { N. } \\
\text { Midland }\end{array}$ & $\begin{array}{c}21 \\
(22 \%) \\
14 \\
(31 \%)\end{array}$ & $\begin{array}{c}16 \\
(17 \%) \\
15 \\
(33 \%)\end{array}$ & $\begin{array}{c}6 \\
6 \%) \\
(6 \%) \\
8 \\
(18 \%)\end{array}$ & $\left\{\begin{array}{l}\text { Liverpool } \\
\text { Manchester } \\
\text { All Prov. }\end{array}\right.$ & $\left.\begin{array}{r}24(26 \%) \\
14(15 \%) \\
6(13 \%)\end{array}\right\}$ & $\begin{array}{l}94 \\
45\end{array}$ \\
\hline Midland & $(23 \%)$ & $\begin{array}{c}8 \\
(15 \%)\end{array}$ & $\begin{array}{l}3 \\
(6 \%)\end{array}$ & Birmingham & $13(25 \%)$ & 52 \\
\hline E. England & $\begin{array}{c}35 \\
(76 \%)\end{array}$ & $\begin{array}{r}3 \\
(7 \%)\end{array}$ & $\begin{array}{l}2 \\
2 \\
(4 \%)\end{array}$ & All Prov. & $3(7 \%)$ & 46 \\
\hline S.E. England & $\begin{array}{c}62 \\
(77 \%)\end{array}$ & $\begin{array}{r}12 \\
(15 \%)\end{array}$ & $(270)$ & All Prov. & $5(6 \%)$ & 81 \\
\hline S. England & $\begin{array}{l}34 \\
(71 \%)\end{array}$ & $\begin{array}{c}8 \\
(17 \%)\end{array}$ & $\begin{array}{c}2 \\
(4 \%)\end{array}$ & All Prov. & $3(6 \%)$ & 48 \\
\hline S.W. & $\begin{array}{c}30 \\
(67 \%)\end{array}$ & $\begin{array}{c}1 \\
(2 \%)\end{array}$ & $\begin{array}{l}(4 \%) \\
2 \\
(4 \%)\end{array}$ & Bristol $\ldots$ & $5(11 \%)$ & 45 \\
\hline London & $\begin{array}{l}117 \\
(75 \%)\end{array}$ & $\begin{array}{l}14 \\
(9 \%)\end{array}$ & $\begin{array}{c}6 \\
(4 \%)\end{array}$ & All Prov. & $11(7 \%)$ & 157 \\
\hline Wales & $\begin{array}{r}10 \\
(27 \%) \\
\end{array}$ & $\begin{array}{r}5 \\
(14 \%) \\
\end{array}$ & $\begin{array}{l}2 \\
2 \\
(5 \%)\end{array}$ & Welsh Nat. & $13(35 \%)$ & 37 \\
\hline Total & $\begin{array}{c}358 \\
(51 \%)\end{array}$ & $\begin{array}{l}110 \\
(15 \cdot 7 \%)\end{array}$ & $\begin{array}{c}32 \\
(4 \cdot 6 \%)\end{array}$ & $\begin{array}{r}170 \\
(24 \cdot 3\end{array}$ & $\% \%^{\circ}$ & 701 \\
\hline
\end{tabular}

TABLE IV.-Settlement of General Practitioners

\begin{tabular}{|c|c|c|c|c|c|c|c|c|c|c|c|c|c|c|}
\hline \multirow{2}{*}{\multicolumn{3}{|c|}{$\begin{array}{c}\text { Student } \\
\text { Residence }\end{array}$}} & \multicolumn{11}{|c|}{ Present Residence } & \multirow[b]{2}{*}{ Total } \\
\hline & & & \multirow[b]{2}{*}{$\begin{array}{c}\text { N. } \\
\text { Eng. } \\
65(61 \%) \\
9 \\
7 \\
4 \\
\frac{1}{2} \\
\frac{2}{3} \\
3\end{array}$} & \multirow[b]{2}{*}{\begin{tabular}{|c|} 
E./W. \\
Yorks \\
8 \\
$59(47 \%)$ \\
6 \\
5 \\
2 \\
2 \\
$\frac{1}{1}$ \\
1 \\
1 \\
\end{tabular}} & \multirow[b]{2}{*}{\begin{tabular}{|c|} 
N.W. \\
Eng. \\
12 \\
22 \\
$116(62 \%)$ \\
3 \\
8 \\
$\frac{4}{4}$ \\
1 \\
2 \\
11 \\
6
\end{tabular}} & \multirow[b]{2}{*}{\begin{tabular}{|c|} 
N. \\
Mid. \\
4 \\
15 \\
5 \\
$35(46 \%)$ \\
7 \\
5 \\
3 \\
4 \\
3 \\
8 \\
- \\
\end{tabular}} & \multirow[b]{2}{*}{$\begin{array}{c}\text { Mid. } \\
2 \\
3 \\
14 \\
6 \\
48(54 \%) \\
7 \\
1 \\
5 \\
4 \\
9 \\
7\end{array}$} & \multirow[b]{2}{*}{$\begin{array}{c}\begin{array}{c}\text { E. } \\
\text { Eng. }\end{array} \\
3 \\
6 \\
4 \\
8 \\
6 \\
26(36 \%) \\
19 \\
3 \\
3 \\
22 \\
5 \\
\end{array}$} & \multirow[b]{2}{*}{\begin{tabular}{|c|}
$\begin{array}{c}\text { S.E. } \\
\text { Eng. }\end{array}$ \\
5 \\
3 \\
6 \\
3 \\
5 \\
13 \\
$67(53 \%)$ \\
11 \\
7 \\
32 \\
5 \\
\end{tabular}} & \multirow[b]{2}{*}{ 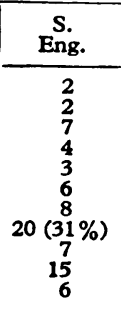 } & \multirow[b]{2}{*}{$\begin{array}{c}\text { S.W. } \\
\text { Eng. } \\
4 \\
4 \\
9 \\
5 \\
7 \\
3 \\
14 \\
15 \\
41(54 \%) \\
19 \\
5\end{array}$} & \multirow[b]{2}{*}{$\begin{array}{c}\text { Lond. } \\
1 \\
2 \\
8 \\
3 \\
2 \\
8 \\
7 \\
2 \\
7 \\
96(44 \%) \\
9\end{array}$} & \multirow[b]{2}{*}{$\begin{array}{c}\text { Wales } \\
\frac{1}{1} \\
\frac{4}{2} \\
\frac{2}{-} \\
61(57 \%)\end{array}$} & \\
\hline $\begin{array}{l}\text { N. England } \\
\text { E./W. Yorks } \\
\text { N. W. England } \\
\text { N. Middland } \\
\text { Midland .. } \\
\text { B. Bngland } \\
\text { S.B. England } \\
\text { S. England } \\
\text { S. W. England } \\
\text { London .. } \\
\text { Wales .. } \\
\end{array}$ & $\begin{array}{l}\because \\
\because \\
\because \\
\because \\
\therefore \\
\because \\
\because \\
\therefore\end{array}$ & $\begin{array}{l}\cdots \\
\cdots \\
\cdots \\
\cdots \\
\cdots \\
\cdots \\
\cdots\end{array}$ & & & & & & & & & & & & $\begin{array}{r}107 \\
126 \\
186 \\
76 \\
89 \\
72 \\
127 \\
64 \\
76 \\
217 \\
107\end{array}$ \\
\hline Total & $\cdots$ & $\ldots$ & 96 & 86 & 185 & 89 & 106 & 105 & 157 & 80 & 126 & 145 & 72 & 1,247 \\
\hline $\begin{array}{l}\text { Scotland .. } \\
\text { N. Ireland } \\
\text { Eire } \\
\text { Commonwealth } \\
\text { Other .. } \\
\text { Unknown .. } \\
\end{array}$ & $\begin{array}{l}\because \\
\because \\
\because \\
\cdots\end{array}$ & $\begin{array}{l}\ldots \\
\cdots \\
\cdots \\
\cdots \\
\end{array}$ & $\begin{array}{r}26 \\
7 \\
4 \\
1 \\
2 \\
-\end{array}$ & $\begin{array}{r}15 \\
7 \\
5 \\
5 \\
1\end{array}$ & $\begin{array}{r}40 \\
14 \\
27 \\
5 \\
9 \\
1 \\
\end{array}$ & $\begin{array}{r}28 \\
6 \\
16 \\
1 \\
1 \\
-\end{array}$ & $\begin{array}{r}19 \\
11 \\
7 \\
5 \\
7 \\
-\end{array}$ & $\begin{array}{l}9 \\
7 \\
7 \\
7 \\
5 \\
2\end{array}$ & $\begin{array}{r}14 \\
2 \\
9 \\
6 \\
7 \\
-\end{array}$ & $\begin{array}{l}\frac{14}{5} \\
\frac{2}{1}\end{array}$ & $\begin{array}{r}12 \\
4 \\
4 \\
3 \\
2 \\
-\end{array}$ & $\begin{array}{r}17 \\
5 \\
23 \\
14 \\
17 \\
1\end{array}$ & $\begin{array}{l}7 \\
2 \\
5 \\
- \\
-\end{array}$ & $\begin{array}{r}201 \\
65 \\
112 \\
44 \\
55 \\
6\end{array}$ \\
\hline \multicolumn{2}{|c|}{ Gross total } & $\cdots$ & 136 & 119 & 281 & 141 & 155 & 142 & 195 & 102 & 15,1 & 222 & 86 & 1,730 \\
\hline
\end{tabular}

$50.8 \%$ of those originally from England and Wales have settled in the region where they lived as medical students. 
TABLE VI.-Settlement of Consultants



Table VI also shows that consultants have tended to scatter rather more widely than general practitioners, and that a significantly smaller proportion $(\mathrm{P}<0.01)$ of consultants have settled in the region where they lived as students.

The absence of a "south-easterly drift" of general practitioners is confirmed on examining the movements of those who came from the North of England or the Midlands to medical schools in London (Table VII). Only 2 of 108 remained in London and 10 more in South-Eastern England; 64 of 108 (59\%) returned to the North and Midlands. Movement in the other direction has more than made up for the small losses ; $23(12 \%)$ of 191 Londoners and $7(6 \%)$ of 112 former residents of South-Eastern England have moved into the North and Midlands, which altogether have gained 60 general practitioner graduates and lost 42 to other parts of England. Londontrained consultants who belong to the North and Midlands are less likely to return than to stay in the South-East or in the London area (Table VIII); only 14 out of 49 (29\%) returned,

TABLE VII.-General Practitioners, London Schools
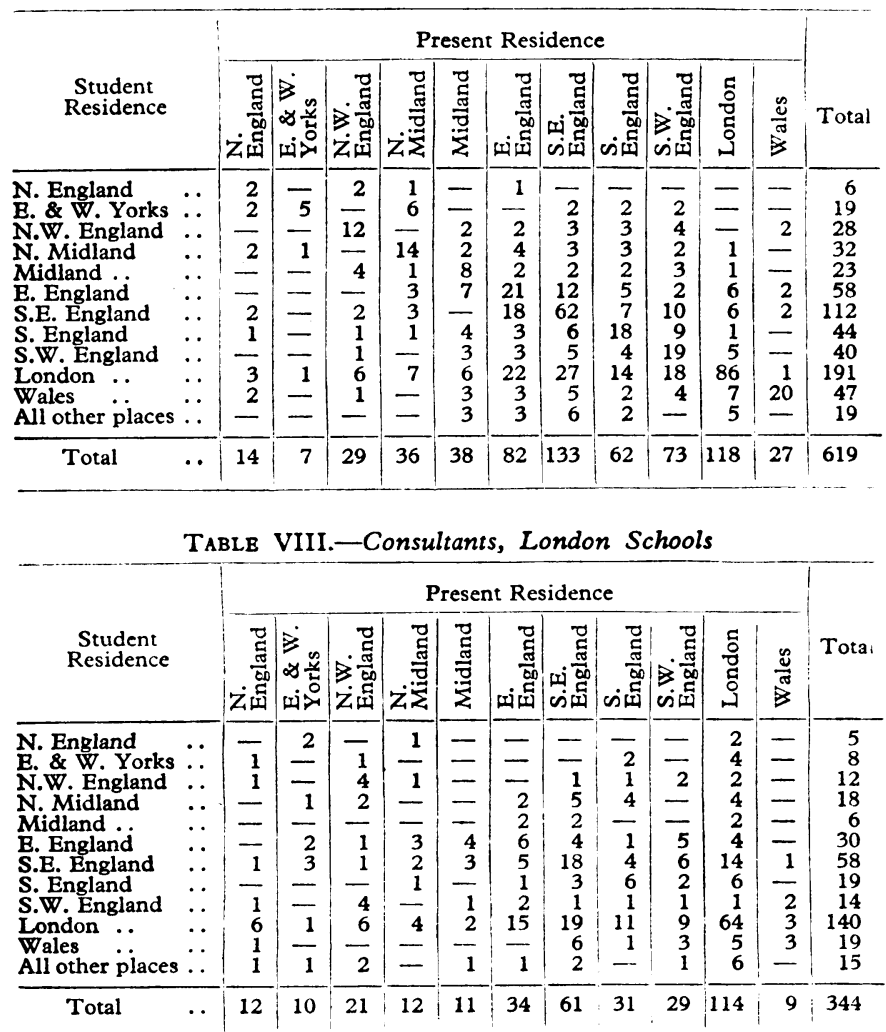

and the rest have nearly all stayed in London or in SouthEastern England. However, the North and the Midlands have gained 52 London-trained consultants from other regions, amply compensating for the loss of 35 who failed to return home.

The greater mobility of consultants no doubt reflects the fiercer competition for vacancies, especially in the first decade after the 1939-45 war; and it also suggests that consultants regard pursuit of their chosen career as more important than settlement in a particular part of the country. Analysis of answers to a further question provide confirmation of this.

Respondents were asked if they had settled in the region of their first choice and if they were practising in the specialty of their first choice. Their replies indicate that consultants more often put their career first and general practitioners more often put choice of dwelling-place first, if these priorities conflict. Thus $22 \%$ of general practitioners but only $13 \%$ of consultants who had settled in the area of their first choice said that they would have preferred a different specialty. However, $36 \%$ of consultants and $26 \%$ of general practitioners who were following the specialty of their first choice said they would have preferred to live in a different part of the country. The differences are small and the method of inquiry insensitive; interviews would be required to establish the validity of the finding.

\section{Provincial Medical Schools and Regional Supply of Doctors}

It has been suggested that the needs of a region which is short of doctors can be met by building a medical school there in the expectation that its graduates will settle locally and make good the deficit. However, the evidence from this inquiry suggests that an alternative policy would be equally successful, at any rate so far as general practice is concerned. As already pointed out, more London-trained general practitioners belonging to the North, the Midlands, or the West of England have returned home to practise than have remained in London (Table VII) ; but provincial regions in England have lost more general practitioners by the departure of graduates who resided locally as students than they have gained by local settlement of graduates belonging to other parts of the country. For example, Manchester draws $96 \%$ of its general practitioner graduates from North-Western England, the North Midlands, and the Midlands. However, $20 \%$ of these have removed to regions further south and only two from other regions (one from the North) have settled locally. The regional gains and losses of the provinces as a result of these movements are shown in Table IX.

Losses of consultants compared with those of general practitioners are proportionately greater, but their significance is 
debatable in view of the greater mobility of consultants. Only the South-Western region has gained more than it has lost as a result of these interchanges. Perhaps climate as well as the laws of supply and demand has played a part.

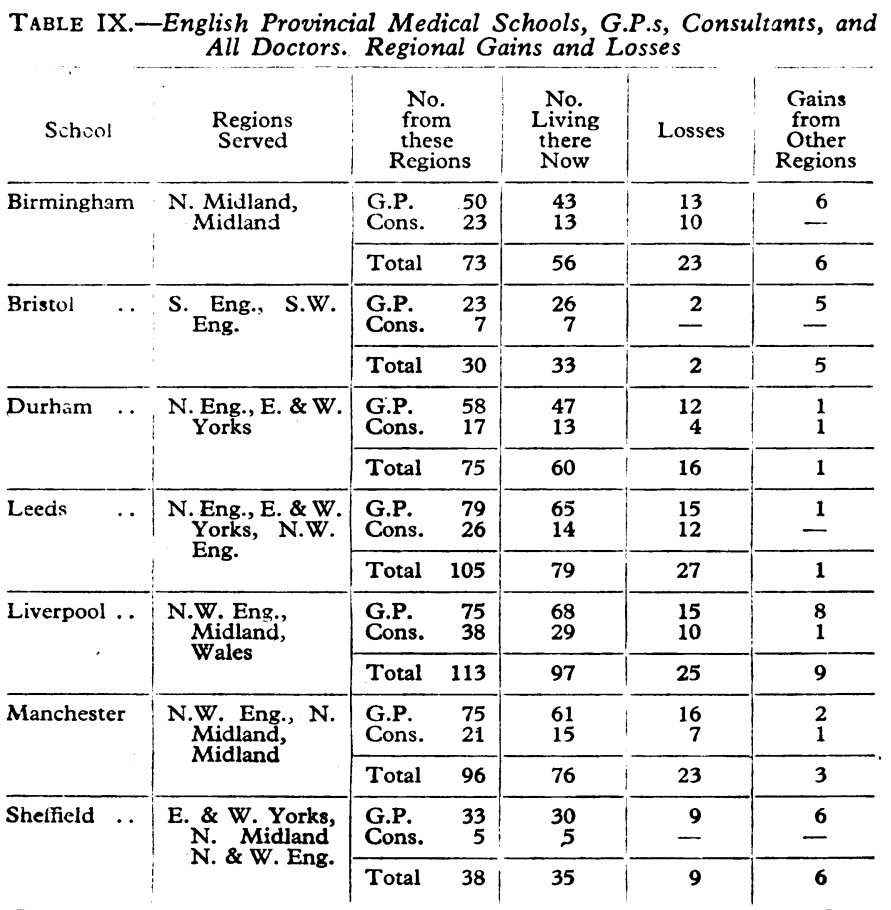

The evidence suggests that a region short of doctors would be helped more by recruiting larger numbers of students from families resident in its area than by establishing a local medical school. This solution would also be cheaper and would perhaps produce quicker results.

\section{Social and Demographic Findings}

In these samples $92 \%$ of general practitioners and $93 \%$ of consultants were male. Approximately a fifth of both general practitioners and consultants came from medically qualified families, but there is a secular trend in family recruitment to medicine. Over $25.5 \%$ of consultants and $20.1 \%$ of general practitioners who qualified before the war came from medical families, but the proportion of both general practitioners and consultants from medical families has declined among more recent graduates, falling to $15 \%$ of consultants and $19 \%$ of general practitioners who qualified in 1950 or later (but numbers of consultants in this group are small). General practitioners are more likely to follow in their father's footsteps than consultants ; $79.9 \%$ of general practitioners and only $19 \%$ of consultants with medically qualified parents have entered the same field of work as their parent. However, the chances of these events are obviously unequal and these differences have no meaning in themselves.

Sixty-six per cent. of general practitioners and $60 \%$ of consultants are practising in the part of the country of their first choice. Those who are not are most likely to have qualified in the decade beginning at the end of the second world war. Their movements have been most influenced by the excess of applicants over vacancies for consultant posts and principals in general practice. Of 487 general practitioners for whom general practice was not the first career choice, $144(29.6 \%)$ would have preferred a career in surgery had an opening been available, $68(14 \%)$ would have preferred a career in obstetrics and gynaecology, $59(12 \%)$ in internal medicine, and $41(8 \%)$ in paediatrics. Among 117 consultants not practising in the specialty of their first choice, most would have preferred a
" main-stream" specialty (medicine or surgery) to a career in a "minor" specialty, and $26(22 \%)$ would have preferred to be in general practice.

\section{Summary}

A postal inquiry among general practitioners and consultants in the National Health Service in England and Wales has shown that general practitioners more often than consultants settle in the part of the country where they spent their youth rather than close to the medical school they attended if these were in different regions. It can therefore be concluded that regions short of doctors would be more effectively, expediently, and economically helped to overcome the shortage by a larger recruitment of students from these regions, rather than by establishing medical schools there. Consultants more often than general practitioners train at London teaching hospitals and tend to diffuse more widely throughout the country rather than to settle close to the place where they lived while they were medical students.

This investigation was supported by a grant from the Nuffield Provincial Hospitals Trust. The friendly co-operation of many general practitioners and consultants in yet another postal inquiry is gratefully acknowledged.

\section{Appendix}

Patterns of Settlement of Doctors in the National Health Service

1. NAMB OF DOCTOR

2. ADDRESS

3. Medical School(s) AtTended

4. Year of GRaduation.

5. PERMANENT RESIDENCE BEFORE MEDICALLY QUALIFIED

Could you please indicate with a tick in which of the undermentioned regions your family home was situated before you qualified in medicine. If you lived in more than one, please tick each, and indicate the order by writing alongside " 1 ," " 2 ," etc.

Northern England (Northumber- South-Eastern England (Surrey, land, Cumberland, Westmorland, Durham, N. Riding of Yorkshire)

East and West Ridings of Yorkshire

North-Western England (Lancs, Cheshire)

North Midland (Derbyshire, Leics, Notts, Northants, RutLeics, Notts,

land, Lincs)
Midlands (Staffs, Shropshire, Herefordshire, 'Worcs, Warwickshire)

Eastern England (Norfolk, Huntingdon, Suffolk, Cambs, Ely, Beds, Herts, Essex) ....... Sussex, Kent) Southern England (Oxon, Bucks, Berks, Hants, I.O.W., Dorset)

South-Western England (G̈lo.: Somerset. Devon, Wilts, Cornwall)

Greater London

Wreates

Wales

Scotland $\quad$.......

Northern Ireland, Isle of Man....... Eire

British Commonwealth Country

Other

.......

6. Could you please indicate in which of the following types of community your family home was situated while you were a medical student :

Large conurbation (city or suburban area) (city or Small urban area $(10,000-$ 50,000 pop.)

Urban area (over 50,000 pop.)...... Village or rural area

7. Were either of your parents medically qualified ? Yes...... No...... If "Yes," have you entered the same field of work ? Yes...... No......

8. PRESENT SITUATION

Please state the year you entered your present field of work ............ Please state the year you settled in the region where you live now .......

9. Are you settled in the part of Britain of your first choice ?

Yes...... No......

10. (IF MARRIBD)

Are you settled in the part of Britain of your spouse's first choice ? Yes...... No......

11. Is your present field of work your first choice? Yes..... No..... 12. If "No," what was your first choice? Please specify.

If you would care to make any general comments on matters related to the subject of this inquiry could you please use the reverse side of 